\title{
Ad obstructos intellectus: da superfície à profundidade em A Ciência da Cruz de Edith Stein
}

\author{
Ad obstructos intellectus: From surface to depth in \\ The Science of the Cross by Edith Stein
}

\author{
Elisângela Pereira Machado* \\ Leomar Antônio Brustolin**
}

\section{RESUMO}

Edith Stein em seu fenomenológico caminho pessoal faz a experiência do adentrar-se no profundo pouco conhecido. Ela rompe as obstruções de um cotidiano ordinário e segue além de uma intelectualidade cuja verdade é sempre buscada com afinco. Este artigo apresenta como o pensamento steiniano ilumina o ser humano contemporâneo na busca de sair da superficialidade e adentrar na profundidade da existência onde se encontra o sentido da vida. Em virtude disso, o intento deste artigo é apresentar reflexões presentes na obra Ciência da Cruz de Edith Stein, baseada na Doutrina Mística de João da Cruz que propõe uma comunicação com Deus consciente e definitiva. Isso consiste em um avançar para além da razão e do intelecto em tempos de estagnação, superfície e vazio.

Palavras-chave: Conhecimento. Cruz. Deus. Fé. Graça.

\section{ABSTRACT}

Edith Stein, in her phenomenological personal journey, makes the experience of going into the unfamiliar depth. It breaks the obstructions of an ordinary day-to-day life and follows beyond an intellectuality whose truth is always sought earnestly. This article presents how Steinian thinking illuminates the contemporary human being in the quest to escape from superficiality and to penetrate the depth of existence, where the meaning of life is found. In view of this, the purpose of this paper is to present reflections present in Edith Stein's Science of the Cross, based on the Mystical Doctrine of John of the Cross, that proposes a conscious and definitive communication with God. It is about moving beyond reason and intellect in times of stagnation, surface and emptiness.

Keywords: Knowledge. Cross. God. Faith. Grace.

\footnotetext{
* Mestra em Filosofia moral e ética pela UNISINOS. Doutoranda em Teologia Sistemática pela PUCRS.<elispmachado@gmail.com>.

** Doutor em Teologia pela Pontificia Università San Tommaso, em Roma, Itália (2000). Professor e coordenador do Programa de Pós-Graduação em Teologia da PUCRS, em Porto Alegre. <leomar.brustolin@pucrs.br>.
} 
Tratar de ciência é tratar de verdades conhecidas, descobertas, desveladas. Quão utópica é a pretensão de um conceito a priori de ciência que transita entre a dóxa e o dogma e que se esquiva das aparências. Das observações carregadas de teorias que a ciência alavanca em sua etimologia - o pensar e o conhecimento - fazem do humano uma espécie primordial dentre as demais espécies em sua compreensão e desenvolvimento: a espécie humana.

Assim, a humanidade difere das demais espécies porque os seres humanos, munidos de órgãos sensoriais apropriados para desvelar o mundo, são também os sujeitos, objetos e aparência deste mundo. Todavia, mesmo dotada de uma inclinação e habilidade para pensar além dos limites, no decorrer dos tempos, tornou-se prisioneira da modernidade que cada vez mais condiciona o pensamento à servidão de uma ciência refém do progresso e da técnica.

Imersa neste cenário que se modifica de modo constante e rapidamente, encontramse as investigações de Edith Stein (1891-1942). Ela se depara, em sua vida, com o mal recorrente da renúncia do pensar, renúncia que lança o humano no abismo do mal, da banalidade, do supérfluo conhecimento e da negação da alma.

Sem a pretensão de ser definida como pensadora profissional, Stein, bem como os gregos antigos, sofreu a paixão do ver, a sede do saber, o intento pela busca da verdade. Desse modo, provocada pela ação do humano e instigada pela natureza fenomênica do mundo, ela oportunizou uma retomada emergente do sentido do ser e do pensar mais elevado que não tem, como objetivo primeiro, a resolução de problemas, mas que é avanço na existência. Um percurso que revela a importância da busca por uma raiz profunda, reflexiva, um saber cuja saída espiritual e intelectual é de suma importância para compreender e superar a natureza do mal que repousa no ordinário da contingência humana.

Edith Stein, judia, filósofa, educadora, teóloga e mártir foi uma figura marcante de espírito fortemente especulativo que transitou pelos corredores de algumas das principais ciências preponderantes do século XIX, a saber: História, Psicologia, Filosofia e Teologia. Uma vida marcada pela vivacidade de espírito e pela curiosidade, empática diante das questões do humano e de sua inserção na sociedade. Para ela, superar-se a si mesmo é dever do humano para chegar a compreender o ser de Deus como fundamento de sua realidade contingente e finita. Ela oferece em suas investigações, o plausível e o perturbável no que se refere ao destino do humano em um mundo partilhado com as demais espécies.

A ciência que Stein elucida na obra $A$ ciência da cruz $^{1}$ não trata de mera teoria e relação de proposições autênticas ou verdadeiras ou da construção ideal baseada em pensamentos coerentes constatáveis de partes que ignoram o todo. Ela especula uma verdade real, viva e operante no universo do humano. Sua ânsia pela verdade não era abstrata, mas pautada em perguntas que a angustiavam a ponto de provocar nela uma crise existencial. Para isso, ela realiza uma imersão, sem volta, na misteriosa contradição do símbolo da cruz e das consequências de quem a compreende, aceita e segue. No atordoamento do entendimento natural, do estranhamento de todas as coisas, especialmente de si mesmo, Stein descreve a jornada de um ser anímico que encontra Deus, morre e ressuscita com Ele.

${ }^{1}$ STEIN, E. Obras completas: Escritos espirituales. Vol. V, p. 183-477. 
A filósofa agrega o pensar, a sede de saber e de encontrar a verdade junto do crer que se complementam, assim como fides et ratio caracterizadas por São João Paulo II, como sendo "duas asas, com as quais, o espírito humano se eleva à contemplação da verdade" ". Afinal, "a Igreja, jamais alheia ao caminho da pesquisa, conta sempre mais, com a filosofia e as demais ciências no que se refere ao esforço de desvelar e desenvolver as verdades fundamentais da existência humana"’. Há, portanto, no pensamento steiniano, uma fusão de ideias possíveis e necessárias que intentam superar e dilatar o contentamento de verdades parciais e provisórias, dinamizando no humano as perguntas radicais sobre o sentido e o fundamento de sua vida pessoal e social.

Os limites do presente artigo não permitem abordar com profunda coerência a densidade da obra em questão. O intento é despertar a relevância de retomar a obra e reconhecer nela a via reflexiva para superar a superficialidade do pensar, a perda de seu sentido e a obstrução de intelectualidades.

\section{O PROPÓSITO DE A CIÊNCIA DA CRUZ}

A preocupação com a dignidade humana é um percurso comum nas investigações de Stein. Parafraseando o sábio Terêncio, "nada do que é humano lhe foi indiferente"4; toda a sua obra é embasada pela experiência vívida dos acontecimentos históricos de sua época. Para ela, há algo em germe no humano pela própria natureza, o qual é preciso encontrar, desvelar, pois a vida, mesmo imersa em riquezas materiais ou conhecimentos tecnocientíficos, carece de sentido e busca algo a mais, de modo que é preciso vigilância e abertura nessa jornada investigativa do ser. Nesse sentido, Stein traz em seu currículo existencial, a preocupação com o humano e o apelo ao sentido da reflexão profunda uma busca da verdade e suas intenções, o seu propósito no mundo.

A verdade é uma temática cara à investigação steiniana; ela se deixou conduzir pela busca da verdade que em toda a sua vida empreendeu, até a culminância de um encontro derradeiro com o sentido último do pensar humano: Deus, o Cristo crucificado. A criatura humana para Stein não é apenas um feixe de saberes e aprendizagens, mas, em sua natureza, um ser espiritual que é convidado a adentrar-se no mistério que supera limites do natural e do sobrenatural. Ela desenvolve seu trabalho e o intensifica quando se depara com os "sinais naturais de que a humanidade se encontra em um estado de corrupção, insensibilidade e frieza, incapaz de compreender o estado das coisas conforme seu verdadeiro valor interior e responder"s.

A obra A ciência da Cruz, é um estudo realizado por ocasião da celebração do IV centenário de nascimento de João da Cruz (1542-1942). É escrita por Edith Stein numa escassez de tempo e em meio a uma delicada realidade social política. Nove meses depois de dar início ao livro, Stein foi retirada do convento, conduzida pela Gestapo ${ }^{6}$ e levada para um campo de concentração, de onde nunca mais retornaria, deixando, contudo, seu testemunho de vida intelectual, consagração monástica e liberdade.

\footnotetext{
2 JOÃO PAULO II. Fides et Ratio. Carta Encíclica aos Bispos da Igreja sobre as relações entre fé e razão.

3 JOÃO PAULO II. Fides et Ratio. Carta Encíclica aos Bispos da Igreja sobre as relações entre fé e razão.

${ }^{4}$ Cf. Nihil humani a me alienum puto - nada do que é humano me é estranho. Frase atribuída a Públio Terêncio Afro, comediógrafo latino do século 2 a.C.

${ }_{5}^{5}$ Cf. STEIN, E. Obras completas: Escritos espirituales. Vol. V, p. 206.

${ }^{6}$ A Gestapo foi criada em 26 de abril de 1933, na Prússia, a partir da Polícia Secreta Prussiana. No início, era apenas um ramo da polícia prussiana conhecida como "Departamento Policial do Estado Prussiano". Seu primeiro comandante foi Rudolf Diels que recrutou membros de departamentos policiais profissionais e fez com que ela funcionasse como uma Polícia federal, semelhante ao FBI dos Estados Unidos. O papel da Gestapo como polícia política só foi estabelecido quando Hermann Göring foi designado para suceder a Diels como comandante em 1934. O termo Gestapo vem da abreviação de Geheime Staatspolizei (Polícia secreta do Estado) e levou o governo nazista a expandir sua força para além da Prússia, para toda a Alemanha.
} 
Vale a ressalva que $A$ ciência da Cruz é decorrente da experiência pessoal de um encontro com Deus no âmago mais profundo de Stein que irrompe com a ciência filosófica ${ }^{7}$ e dá lugar à ciência da cruz em seu próprio ser, em sua alma. No caminho para o campo de concentração, Stein, ou melhor, Irmã Teresa Benedita da Cruz, escreve um bilhete para sua priora: "Estou feliz por tudo. Uma ciência da cruz só se pode adquirir experimentando a fundo a cruz (...) repito em meu coração - Ave, Crux spes unica"

A cruz não enquanto um fim em si mesmo, mas enquanto um meio para se chegar à plenitude da vida. Uma experiência indelével de proximidade com o mistério que a acompanhou e conduziu até os seus últimos dias no interesse também pela teologia. Ora, sabe-se que o pensamento teológico na cultura ocidental nasceu entrelaçado ao pensamento filosófico. Em virtude disso, a obra de Stein, envolve o entrelaçamento destes saberes, especialmente, de Aristóteles, Tomás de Aquino e da fenomenologia moderna9.

Na integração da melhor contribuição das ideias dessas autoridades, Stein salienta em seus argumentos a importância da Filosofia e da Teologia para se complementar, fortalecer e imbuir-se da perspectiva e dos elementos da fé. Somente desse modo ambas serão fiéis em sua missão de desenvolver uma ontologia de ascendência do sentido pleno do ser. O desvelar da via espiritual foi para a filosofia de Stein o conteúdo decisivo em seu percurso ontológico pessoal resultando no desenvolvimento de uma antropologia teológica valorosa para os nossos dias. Afinal, a reflexão teológica é movida pela potente experiência que supera e abrange todas as outras, a saber, a experiência da fé reforçada pela Revelação.

Para a filósofa, convertida à monja carmelita, é certo que criaturas espirituais podem reconhecer a possibilidade da realidade da existência de Deus. Isso é possível com o uso da dimensão intelectiva da vida interior ${ }^{10}$, dimensão que submete o ser, consciente ou voluntariamente, à essência, ciência e potências divinas.

Existem sinais naturalmente perceptíveis a indicar que a natureza humana, tal qual a conhecemos, encontra-se em estado de corrupção. Daí a incapacidade de aprendermos intimamente os fatos segundo seu verdadeiro valor e de reagirmos adequadamente a eles. Esta incapacidade pode estar fundamentada em uma deficiência inata da inteligência (estupidez congênita), ou de um embotamento geral que ao longo da vida se tenha formado, e por último, de uma insensibilidade para determinadas impressões, quando frequentemente repetidas. Coisas muitas vezes escutadas deixam-nos frios. Acresce ainda os assuntos de interesse próprio e preocupações particulares que nos tornam inacessíveis a outras coisas ${ }^{11}$.

A investigação de Stein não é algo novo, ela inova no estilo em seu método de abordagem, no esforço contínuo de apreender a peculiaridade da experiência mística e de distingui-la da experiência religiosa tomada em sua generalidade, até mesmo da experiência da fé. Trata-se de uma experiência que ultrapassa a capacidade de compreensão do espírito humano e a capacidade natural da linguagem. Por conseguinte,

\footnotetext{
7 A psicologia pela qual optou por iniciar seus estudos universitários não dava uma resposta convincente à sua busca, mas a ajudou em grande parte no seu conceito experiencial da pessoa; tampouco a filosofia lhe proporcionou um caminho convincente. Foi o método fenomenológico que abriu um novo caminho, uma diferente forma de confrontar-se com a realidade; desde a observação direta e mediante a experiência de deixar que a essência do contemplado apareça. Cf. FERMÍN, F. J. Sancho. Lineas generales de la espiritualidad de Edith Stein, p. 75.

${ }^{8}$ Cf. STEIN, E. Obras completas:. Escritos autobiográficos e cartas. Vol. I, p. 1383. Carta no 653 para A. Antonia Engelmann.

${ }^{9}$ A pedra de toque do pensamento steiniano é a constante tentativa de realizar um diálogo profundo entre filosofia e fé presentes em Edmund Husserl e São Tomás de Aquino.

${ }^{10}$ Cf. SAVIAN FILHO, J. Experiência mística e filosofia em Edith Stein, p. 175.

${ }^{11}$ Cf. STEIN, E. Obras completas: Escritos espirituales. Vol. V, p. 206.
} 
Stein expõe em A ciência da Cruz uma linguagem poética e simbólica, um estilo utilizado pelos santos em suas tentativas imanentes de enunciarem a transcendência. Ela busca auxílio nas expressões - noite e cruz - presentes em textos de São João da Cruz e Santa Teresa D'ávila ${ }^{12}$, expressões que clarificam o roteiro para o ser humano na jornada rumo à certeza interior, a dimensão primordial na qual Deus mesmo fala, uma experiência sobrenatural distinta do conhecimento intelectual e da fé. Cruz e noite, espírito e fé, relações de morte e ressurreição espiritual seguidas pelo esplendor da vida e do matrimônio da alma ilustram toda a ciência da cruz de Stein.

\section{A VIA ILUMINATIVA DO PENSAR STEINIANO}

Encontramos em A ciência da Cruz um percurso existencial e espiritual que todo humano é chamado a percorrer. Em sua natureza o ser humano não é um ser meramente jogado no mundo. Há nele um projeto, um destino do espírito do ser anímico rumo à verdade. A verdade em Stein resulta numa tomada de decisão e num comprometimento que ele incorporou de modo radical. Amiúde, o humano deixa-se enganar por pseudoverdades, mesmo assim, em todas as ideias há uma centelha da verdade eterna. Desse modo, é no tocante à necessidade de uma ressignificação do pensar e do tomar decisões enquanto via preventiva do perigo que se esconde na irreflexão humana que as investigações de Edith Stein demonstram sua relevância e atualidade.

Sob forte influência da filosofia clássica grega e do pensamento de Kant e Heidegger, ela retoma algumas diferenças fundamentais entre os seres humanos e os animais mediante a estrutura linguística proposicional de que o ser consciente elabora e se objetiva. O humano não se limita a reações diante de uma situação dada, mas comportase em relação a si mesmo. Ele desenvolve uma linguagem onde estão presentes elementos de uma estrutura teórica e prática. Desse modo, diferente das demais espécies, o humano afirma, nega, reflete, posiciona-se, escolhe, é livre e justifica suas afirmações e decisões mediante razões e juízos. Uma vez que dotado de juízo sempre terá muito que discernir e agir. ${ }^{13}$

A possibilidade de mover-se em si mesma se funda na possibilidade de formação do "eu" da alma. O "eu" é na alma aquilo que permite à alma abranger a si mesma e o que nela se move como num campo próprio [...]. O humano é chamado a viver em seu interior mais profundo, a ser dono de si mesmo, o que só é possível neste ponto de apoio. Somente assim poderá decidir e assumir o lugar que lhe compete no mundo ${ }^{14}$.

Sempre haverá, entretanto, algo que o humano desconhecerá, mas que também ele sempre sofrerá da inquietante busca de alargamento no que se refere aos seus saberes e orientações. Enquanto ser reflexivo, todo humano está implicado na tarefa de indagar sobre o sentido de seu existir, pensar, saber, crer e decidir. Tudo que lhe compete requer interpretação referente ao cenário da mente pensante que habita. Para Stein "o conhecer é sempre um passo do não saber ao saber" ${ }^{15}$.

\footnotetext{
${ }^{12} \mathrm{~A}$ autora se utiliza da linguagem simbólica presente em textos espirituais de Santa Teresa D’ávila (1515-1582), autora do Livro da Vida, obra que decanta a sua conversão e da Doutrina Mística de São João da Cruz (1542-1591), para desenvolver mais claramente a sua análise acerca do caminho místico do espírito. Uma linguagem poética e não doutrinal que contribuem para a melhor compreensão e apreensão do mistério no limitado entendimento humano.

${ }^{13}$ Sobre a verdade do juízo cf. STEIN, E. Ser finito e ser eterno, p. 315.

${ }^{14}$ Cf. STEIN, E. Obras completas: Escritos espirituales. Vol. V, p. 341.

${ }^{15}$ Cf. STEIN, E. Obras completas: Escritos espirituales. Vol. V, p. 751.
} 
Uma vida sem reflexão é possível, mas, fracassa no desabrochar de sua essência e vivacidade no que diz respeito às suas convicções e escolhas. Afinal, "todo humano é livre e cada dia, em cada momento se encontra sujeito a decisões"16. O pensar se ocupa do que está ausente; nele a verdade está. Na investigação de Stein há um fator predominante neste estado ausente, um fator denominado fé, não enquanto crença apenas, mas certeza daquilo que não se vê, do não comprovável ou observável, obra do entendimento e via iluminativa do espírito que o conduz rumo à verdade.

Quando o intelecto alcança o seu máximo, ele chega aos próprios limites. Ele tenta encontrar a verdade mais sublime e última, e descobre que todos os nossos conhecimentos são apenas fragmentos. Então, quebra-se o orgulho e enxergamos duas coisas: ou ele cai no desespero ou coloca-se em humildade diante da verdade impenetrável e recebe humildemente na fé, o que não pode ser conquistado pela atividade natural do intelecto. Então, o intelecto chega, à luz da verdade divina, à correta sintonia para com seu próprio intelecto ${ }^{17}$.

Mediante a fé, a alma, à medida que se renova e intensifica seu conhecimento de Deus, conhece melhor a si mesma como núcleo da consciência e do amor. A fé ilumina a alma e alavanca o entendimento para o sobrenatural, ou seja, para além de uma ciência natural. Pois, nem a razão, nem os sentidos podem atingir essa instância. "nenhum homem está, por si mesmo, em situação de abarcar com seu olhar, todos os motivos e contra motivos que o fazem ouvir a sua voz interior em uma decisão"18.

O humano só é capaz de decidir conforme seu saber e consciência dentro do que se alcança. O humano que crê, sabe que há $U m$, o melhor saber cujo olhar não se limita a nenhum horizonte, senão, que abarca a realidade toda e a tudo penetra. A respeito desse Um, Stein nomina: Deus, espírito puro e protótipo de todo ser espiritual. A fé, portanto, é garantida por Deus, fator que propicia ao crente a experiência da certeza e da verdade. A travessia da noite descrita na A ciência da Cruz se desenvolve mediante o exercício de pensar e tomar decisões do espirito ${ }^{19}$ porque compreender o inteligível é função própria do espirito. Trata-se então de "uma via na qual Deus mesmo quer nos ensinar" 20.

Essa não é uma tarefa simples segundo Stein, pois, não pode o entendimento por seu próprio meio unir-se perfeitamente a Deus; ele não pode mediante suas próprias forças formar um conceito adequado de Deus. Sequer a memória, com a sua imaginação, pode criar formas ou imagens que possam representar Deus. Logo, para se chegar a Deus é preciso ir até o entendimento que, desejoso de entender, antes cego e diante das trevas, vai abrindo suas potencialidades no intento de superar as coisas e elevar-se em direção ao Deus inapreensível e incompreensível. Daí, mediante a fé, objeto do entendimento ou contemplação, a alma é tomada por "Deus que dela se apodera e a inflama de amor. Amor eterno que é fogo devorador de tudo o que é terreno, finito, perecível”"21. Esse é o caminho do ser, cuja natureza não se reduz ao temporal, mas possui suas raízes na eternidade. Caminho percorrido por Stein em que ela se deixou consumir pelo Amor;

\footnotetext{
${ }^{16}$ Cf. STEIN, E. Obras completas: Escritos espirituales. Vol. V, p. 343.

${ }^{17}$ Cf. STEIN, E. Ser finito y ser eterno, p. 59.

${ }^{18}$ Cf. STEIN, E. Obras completas: Escritos espirituales. Vol. V, p. 345.

${ }^{19}$ Stein em suas investigações fenomenológicas distingue o termo espírito (Geist) em dimensões pessoal e espiritual, sendo a dimensão espiritual entendida de dois modos: espirito como parte superior da alma, distinta da sensibilidade (Mens - mente) que diz respeito às faculdades superiores do humano que oportunizam um agir livre e regrado pelas leis da razão, faculdades estas, também tributárias dos sentidos. Aqui, intelecto/entendimento designam a atividade cognitiva do espírito; o segundo modo é spiritus que qualifica a natureza da alma como alguma coisa espiritual.

${ }^{20}$ Cf. STEIN, E. Obras completas: Escritos espirituales. Vol. V, p. 247.

${ }^{21}$ Cf. STEIN, E. Obras completas: Escritos espirituales. Vol. V, p. 364.
} 
esse percurso, tal qual Paulo, ela o fez: "ambicionai por dons melhores, eu vou indicarvos um caminho infinitamente superior" (1 Cor 12,31).

\section{O LUGAR DE SENTIDO DA NOITE E DA CRUZ}

Sabe-se que uma antropologia integrada move as investigações de Edith Stein. Para ela, a pessoa é ser espiritual, contudo, o ente humano tem de ser entendido como um ser psicofísico formado por um corpo animado, vivo (Leib), dotado de sua alma (Seele - impulsos psíquicos) e de seu espírito (Geist). Em A ciência da Cruz ela se detém nas investigações da alma. Isso porque a alma desempenha um papel primordial na constituição da pessoa; ela é criada diretamente pela mão de Deus e considerada na vida dos místicos ${ }^{22}$, a saber, São João da Cruz e Santa Teresa D’ávila, como sendo o "lugar" onde se dá o encontro com Deus. Deus é o mais profundo centro da alma, e a alma, se encontra "enquanto espírito", no reino do espírito e dos espíritos ${ }^{23}$.

A alma é um espaço, fonte escondida em que o eu se move livremente, externamente, internamente e profundamente ${ }^{24}$. Desse modo, o lugar primordial do encontro com Deus é o propósito da investigação steiniana, não apenas de modo geral, mas, sob a forma de uma energia vital própria, estado de ânimo que em sua peculiaridade quanto mais se eleva até Deus, mais profundamente desce em si mesma. Porque Stein trilhou pessoalmente esta via do avançar de uma contemplação filosófica do ente para a contemplação mística do ser. É nesta perspectiva que encontramos todo o desenvolvimento da espiritualidade steiniana.

É o lugar de sentido e da absoluta iniciativa e manifestação de Deus que penetra no humano, dilatando seus limites, fazendo apreender diretamente e sem medições, a sua presença ${ }^{25}$. Trata-se da forma interna do corpo que o vivifica, dotada em si, de um interior e de um exterior; um interior que é essência e, também, exterior. É nesse movimento de sair de si, no espaço de sua interioridade e liberdade e no envolvimento de suas potências espirituais que o humano decide e desbrava o caminho para o mistério.

Este é o grande mistério da liberdade humana diante da qual se depara o mesmo Deus. Ele não quer exercer seu domínio sobre os espíritos criados senão como um presente livre de seu amor. Ele conhece os pensamentos do coração, penetra no mais profundo abismo da alma onde seu próprio olhar não podia chegar, não podia ser iluminada com a luz especial do propósito. Deus não quer apoderar-se da alma sem que ela mesma consinta. Todavia, Ele não deixará de por, sem dúvida, tudo em jogo, a fim de conseguir que a alma entregue livremente a própria vontade à vontade divina como uma doação que ela faz em seu amor e, de sorte, que Ele possa conduzi-la à ditosa união ${ }^{26}$.

A ciência da Cruz é um convite para uma comunicação e tomada de decisão pela união com Deus, mais ainda, a obra apresenta todo o desenvolvimento da vida espiritual, do conhecimento e posse do ser da alma que alcança seu centro mais profundo e encontra o lugar de sua liberdade e da sua união com Deus, lugar onde se sente como que em sua

\footnotetext{
${ }^{22}$ Para Francisco Fermín, o místic0o é aquele que em seu intento profundo de alcançar Deus abre-se à realidade e à experiencia de uma profunda ascese mental; ele então busca desvencilhar-se de todo prejuízo racionalista e de toda conceitualização apriorística porque sabe que deve "purificar-se", desnudar-se do homem velho para revestir-se do "homem novo", o Cristo - Aquele que nos revela o verdadeiro rosto de Deus. Cf. FERMÍN, F. J. Sancho. Líneas generales de la espiritualidad de Edith Stein, p. 76.

${ }^{23}$ Cf. STEIN, E. Obras completas: Escritos espirituales. Vol. V, p. 333.

${ }^{24} \mathrm{O}$ humano é um ser que diz de si um $e u$; ele tem um corpo vivente, alma e espírito. Seu corpo vivente pessoal é aquele no qual vive um "eu" e pode se configurar em um agir livre e ter domínio sobre si mesmo. Ele não pode sair do seu corpo, estar em outro lugar, essa é uma vivência permitida pela sua atividade intelectual. Todas as suas vivências estão ligadas à consciência do "eu"; nenhum outro animal pode dizer algo sobre si mesmo. Cf. SBERGA, A. A. A formação da pessoa em Edith Stein, p. 106.

${ }^{25}$ Cf. BELLO, A. Teologia negativa, mística, hilética fenomenológica: a propósito de Edith Stein. Memorandum, v. 3, p. 98-111.

${ }^{26}$ Cf. STEIN, E. Obras completas: Escritos espirituales. Vol. V, p. 342.
} 
própria morada ${ }^{27}$. Deste modo, movida pela certeza de que Deus anseia pela unidade, plenitude e beatitude de todo ser, a meta deste pleno encontro somente será atingida quando compreendidos e superados os obstáculos que surgirão.

Seguindo a esteira da reflexão mística de João da Cruz e Teresa D’ávila, Edith Stein oportuniza uma retomada da beleza poética, mas, ao mesmo tempo, do empreendimento desafiador da compreensão dos símbolos da noite e da cruz. Essa simbologia apresentase numa relação em comum de complementação e expressão magistral, abrindo possibilidades de entendimento para o abstrato inefável. Para Stein, "nenhum coração humano se adentrou jamais em uma noite tão escura como a do Homem de Deus no Getsêmani e no Gólgota"28. Nenhum espírito humano poderá penetrar no insondável secreto abandono divino do Homem de Deus moribundo. Realizar a travessia da noite, compreender a mesma e decidir pelo eterno é o único caminho de entrega coerente para o ser partícipe da Encarnação.

[...] Não somente a noite iluminada tem valor, também a noite escura. Dá fim à pressa e agitação do dia, traz o descanso e a paz. Tudo isso também se realiza na noite anímico espiritual. Existe uma suave claridade noturna do espírito, na qual, livre da escravidão dos negócios cotidianos, se sente, ao mesmo tempo, livre e recolhido em profunda harmonia de seu próprio ser e de sua vida, do mundo e do além-mundo. Há um profundo e agradecido descanso na paz da noite ${ }^{29}$.

$\mathrm{Na}$ descrição de Stein sobre a noite em João da Cruz encontra-se um esclarecimento da diferenciação entre noite cósmica e noite simbólica na mística. Ambas "possuem suas especificidades e afetam a alma; elas tratam do desconhecido, do obscuro. Em relação à noite cósmica, natural, ela revela em si, ausência de luz, sombra, e, muitas vezes, um sentido ameaçador. Seu significado é vital, anímico, espiritual e remete à morte. Mas, em outra instância, sua outra face, oportuniza também, a poesia na representação da lua que suavemente ilumina o existir"30.

Os efeitos da noite cósmica tocam na interioridade do ser assim como a noite mística que é experienciada de modo mais intenso toca na interioridade do eu. A noite mística não deve ser entendida cosmicamente; ela não chega a partir do exterior, mas tem sua origem na interioridade e afeta somente a alma em que nela emerge. As noites cósmica e mística dinamizam sensações e experiências na alma solitária que impedem o desenvolvimento de suas potências e abre espaço para as suas angústias e medo. Trata-se de um modo de apreender o espiritual através de algo sensível e conhecido como é a noite cósmica.

No sentido existencial místico, o símbolo da noite expressa uma densa profundidade e um estado de ânimo muito particular que apontam para as obscuras e misteriosas vias que conduzem o ser para a união divina. A noite é guia no itinerário de amor místico até o despontar da luz que abre clareira para os passos do peregrino rumo ao encontro decisivo com a cruz. A cruz é compreendida não como um fim em si mesma, mas como força redentora que eleva e aponta para o alto. Em contradição com a natureza humana

\footnotetext{
${ }^{27}$ Cf. FERMÍN, F. J. S. Lineas generales de la espiritualidad de Edith Stein, p. 81.

${ }^{28}$ Stein refere-se a Jesus, o Cristo crucificado - sua vida, missão, testemunho revelada na Sagrada Escritura, enfatizada na Teologia da Cruz, desenvolvida e expandida por São Paulo. Paulo desejoso da união plena em Deus, experiencia a força transformadora de uma proximidade íntima do amor incondicional do Cristo; ele esclarece: “[...] a mesma lei me levou a romper com a lei, a fim de viver para Deus. Estou crucificado com Cristo, já não sou eu quem vivo, senão é Cristo quem vive em mim. Agora em minha vida mortal, vivo crendo no Filho de Deus que me amou e se entregou por mim." (Gal. 2, 19-20). Cf. STEIN, E. Obras completas: Escritos espirituales. Vol. V, p. 216.

${ }^{29}$ Cf. STEIN, E. Obras completas: Escritos espirituales. Vol. V, p. 235.

${ }^{30}$ Cf. STEIN, E. Obras completas: Escritos espirituales. Vol. V, p. 234.
} 
que se assombra e evita a noite e a morte, a cruz, símbolo pesado e difícil, aponta para a vida eterna, uma vida que exige renúncia da vida terrena. É o próprio Cristo quem anuncia: "quem quiser me seguir, renuncie a si mesmo, tome a sua cruz e me siga" (Mt 16,24).

Há, portanto, na noite e na cruz, uma intencionalidade salvífica que oportuniza ao humano ver e encontrar Deus mediante o rosto de Jesus. É uma simbologia poética, educativa e necessária, porque o mistério oculto é presença verdadeira, oculta, mas desejosa dessa relação. O simbólico é um instrumento valioso para que o oculto possa manifestar-se. A literatura mística é a prova de que o melhor modo de expressão a respeito de Deus não é a fala conceitual, mas é algo mais: é a porta de entrada para a compreensão e acolhimento do obscuro e luminoso silêncio que rompe com todo entendimento e transforma o ser. Dessa maneira, a graça se comunicará ao humano que desde sempre é chamado ao seu interior mais profundo e lhe permitirá compreender seu lugar no mundo, de modo intenso, desfazendo meras opiniões, ilusões e medos. O encontro com o inalcançável que João da Cruz poetizou sabiamente, deste, apenas um fragmento: "para chegares a saborear o tudo, não queiras ter gosto em coisa alguma, para chegares a possuir tudo, não queiras possuir coisa alguma, para chegares a ser tudo, não queiras ser coisa alguma, para chegares a saber tudo, não queiras saber coisa alguma (...) para chegares ao que não sabes, hás de ir por onde não sabes (...)”.

\section{O DIVINO, A GRAÇA E A MÍSTICA}

Em toda a reflexão fenomenológica steiniana, pensar é realizar um movimento de abertura interior a uma questão a fim de perseguir seu núcleo problemático, o centro de gravidade que suscita e provoca o pensamento, engajando-o no caminho da compreensão. No fundo, trata-se de uma atitude intelectual epistemológica em um movimento libertário rumo a um profundo que abarca uma totalidade, antes, desconhecida. É a experiência do toque divinal, da energia escondida no amago do humano que o atrai mais e mais para uma adesão e uma mudança no modo de situar-se na vida. É preciso lembrar o processo investigativo anterior de Stein acerca da dimensão do humano e de sua interioridade, mais especificamente, presentes em sua tese de doutoramento intitulada O Problema da Empatia ${ }^{31}$.

Stein busca em A ciência da Cruz adentrar na doutrina de João da Cruz. Ela intenta, mediante o uso e resultados de pesquisas modernas, clareza e elevação no que refere à relação mútua entre as já mencionadas três potências do espirito (inteligência, vontade e memória) que formam um elo com as três virtudes teologais da fé, caridade e esperança. Todas essas permeiam a trajetória da alma em seu encontro com Deus. Em virtude disso, a obra apresenta uma distinção dos diferentes modos de habitação divina na alma que recebem o nome de inabitações.

Estas inabitações são níveis ou graus de possibilidade em que a alma acolhe uma relação com o divino, com o sobrenatural e, conforme sua liberdade, move-se para a verdade. Diz respeito a uma união com Deus mediante a diferença de graus da presença da graça e da consumação de amor no existir da espécie anímica. É importante a ressalva

\footnotetext{
${ }^{31}$ Edith Stein já vislumbra a necessidade de aprofundar a análise da dimensão interior da estrutura da alma humana ao se deparar com a necessidade de pensar a possibilidade da relação empática do crente com Deus. Como é possível uma relação empática com uma pessoa espiritual sem a mediação da corporeidade material? Ela se propõe a analisar a experiência da consciência religiosa buscando a compreensão de uma dimensão interior, espiritual, em direção ao núcleo da pessoa. No estudo da consciência religiosa, motivado por um interesse a princípio intelectual, Edith Stein vai experimentando gradativamente uma maior relação de intimidade com Deus: à medida que analisa teoricamente o núcleo da pessoa e se depara com seu próprio interior, ela o vivencia de um modo completamente novo. Cf. PARISE, M. C. I. As colorações da alma na análise da pessoa humana segundo Edith Stein, p. 15.
} 
de que “São João da Cruz e Santa Teresa D’ávila afirmam em perfeito acordo que há uma diferença entre a inabitação divina por graça nas almas e a presença divina comum em todos os seres" 32 .

Isso se dá porque o contato de Deus não pressupõe uma inabitação pela graça; basta que o ser exista, toda alma depende d'Ele. Afinal, para Stein, o humano encontra a razão de seu ser em si mesmo, possui uma capacidade à vida espiritual. Não se trata de uma alma destituída de um corpo, mas da unidade do corpo, da alma e do espírito que são elementos constitutivos deste homem enquanto ser espiritual dotado de uma interioridade em que Deus pode fazer morada em essência, presença e potência; isso acontece, mesmo que as almas endurecidas pela contingência da vida não o saibam ou queiram. A inabitação pela graça somente é possível em seres pessoais e espirituais em que se supõe a livre aceitação da graça santificante recebida.

Portanto, a primeira forma de inabitação de Deus é exposta nas investigações de Stein no plano ontológico da presença divina que não exige do ser em quem Deus está presente outra coisa senão estar submetido à presença da sabedoria e do poder divinos. Algo que é comum a todos os seres criados porque a fé antecede a aproximação natural. Deus habita todas as coisas criadas e Ele as sustenta no ser. Neste nível de conhecimento de Deus, pode haver um toque no íntimo da alma, uma brecha que se abre para o novo, uma centelha De profundis que irrompe, algo como uma inspiração ou iluminação sem que isso signifique uma relação de entrega mútua; "um toque divinal que pode tornar-se um meio, um ponto de partida de capacitar o incrédulo para ser instrumento ideal de um determinado fim" ${ }^{33}$.

É a possibilidade do despertar da fé que resultará na preparação e entrega à graça santificante - uma operação que se estabelece entre Deus e a alma, operada quase que exclusivamente pelo intelecto numa atividade de conhecimento racional. A vontade é solicitada e há ressonâncias na vida afetiva, mas o interesse por Deus é ainda eminentemente intelectual. Há algo como um conhecimento prévio, uma noção da presença divina, quer queira ou não, quer se admita ou não. Esta situação requer o desobstruir do espaço interior progressivamente, tomando distância das solicitações externas que não cessam de assaltar e afastar o $e u$ do interior de sua morada.

A segunda modalidade de inabitação de Deus na alma é aquela em que o ser responde à iniciativa divina. $\mathrm{O}$ ser acolhe o toque, a presença de Deus e estabelece com ele uma relação de amor. Essa modalidade é também denominada fé. Nela há uma unidade entre conhecer, amar e agir resultantes da meditação do conteúdo revelado da fé: "quanto mais fé a alma tem, mais unida está a Deus" ${ }^{34}$. Ela implica uma influência permanente, um contínuo derramar-se de vida e de divino na alma agraciada. É o início do processo do caminho da interiorização. O humano adquire conhecimento de seu ser e de sua destinação, mas isso não significa que haja entrega. Há, contudo, uma profundidade maior que irá caracterizar atos verdadeiramente livres, é o local onde o eu-agora em seu lugar próprio - irá retornar e retirar-se, ponto em que o humano toma decisões definitivas, abandona-se e se doa. Para Stein, "Deus pode infundir na alma um estado de contemplação como graça concedida à mesma; não se trata, contudo, efetivamente, da contemplação adquirida, pois, na contemplação infusa há um contato direto com o ser divino sem a mediação de fórmulas de fé" ${ }^{35}$.

${ }^{32}$ STEIN. E. Obras completas: Escritos espirituales. Vol. V, p. 348

${ }^{33}$ STEIN. E. Obras completas: Escritos espirituales. Vol. V, p. 358

${ }^{34}$ STEIN. E. Obras completas: Escritos espirituales. Vol. V, p. 256

${ }^{35}$ STEIN. E. Obras completas: Escritos espirituales. Vol. V, p. 362. 
Ainda que o conteúdo experimental seja o mesmo na contemplação da fé infusa ou na experiência mística, a diferença está na posse da alma da presença perceptível de Deus. É preciso que o humano permita e desenvolva em si a capacidade de atingir a meta e sinta após experienciar o Mistério que a Presença de Cristo produz a necessidade de uma assimilação, de tornar a vida em si uma vida eucarística ${ }^{36}$. A diferença nos níveis da contemplação da alma resulta nas experiências expostas com rigor e clareza em $A$ ciência da cruz:

Como conhecimento sobrenatural das coisas [...] é o começo da vida divina em nós, porém, é só um começo. Este foi depositado em nós como uma semente da graça santificante; e, sob nossos cuidados terá de brotar e desenvolver-se, até formar uma grandiosa árvore com frutos em abundância. Este é o caminho que há de nos conduzir já nesta vida, à união com Deus ${ }^{37}$.

$\mathrm{Na}$ terceira modalidade da inabitação de Deus na alma, Stein trata da contemplação mística, da união transformadora e divinizante realizadas mediante o amor perfeito. Isso se refere ao conhecimento de Deus e união com Deus, antes, preparado mediante a fé, agora, de forma infusa, também chamado de obscuro e geral; obscuro porque transcende as atividades naturais do entendimento; geral porque nesse conhecimento não há mais lugar para distinções e particularidades produzidas pelos sentidos exteriores ou interiores. Por conceber o conceito místico de diferentes modos no mundo de hoje, a terminologia esvaziou-se em seu significado e sentido. É o dilatar da consciência humana em relação a uma realidade viva e dinâmica que o ser se identifica e se expande em direção o Eterno.

Sempre houve místicos na igreja cristã. Conquanto muitos fossem vistos com desconfiança. Alguns logram favor aos olhos das autoridades. As experiências destes últimos têm sido tratadas como precedentes, e neles se fundou um sistema codificado de teologia mística, em que tudo o que é legitimo encontra o seu lugar. A base do sistema é a oração ou meditação, a metódica elevação da alma a Deus. Pela prática da oração podem atingir-se os níveis mais altos da experiencia mística [...]; a primeira coisa que se deve visar na oração é o desapegar-se da mente das sensações externas, pois estas interferem na sua concentração em coisas ideais ${ }^{38}$.

Para Stein, fé e contemplação mística são duas vias distintas, cada qual com seus graus progressivos. Neste caso, temos o citado exemplo de Teresa D'ávila em seu encontro com a verdade da experiência mística.

É, pois, de fato, uma inabitação diferente da comum a todos os seres criados a que Teresa revelou em sua oração de união. E, esta nova maneira de inabitação nem sempre se dá de fato, nem sequer ali onde em princípio, poderia acontecer. A mesma santa nos deixa entender claramente, quando afirma que a alma tem a certeza de ter estado com Deus e Deus com ela ${ }^{39}$.

É, portanto, a terceira inabitação da união de Deus na alma do ser, um encontro transformador decisivo, radical. O ser no ser da alma é tocado em seu núcleo mais profundo, na centralidade da sua vida pessoal, mas também, no lugar próprio de encontro com outra vida pessoal. Há então, um contato vivificante de um interior

\footnotetext{
${ }^{36}$ Cf. FERMíN, F. J. S. Lineas generales de la espiritualidad de Edith Stein, p. 95.

${ }^{37}$ STEIN. E. Obras completas: Escritos espirituales. Vol. V, p. 352.

${ }^{38}$ Cf. JAMES, W. As variedades da experiencia religiosa, p. 371.

${ }^{39}$ STEIN. E. Obras completas: Escritos espirituales. Vol. V, p. 352.
} 
antes obscurecido que vai se dilatando e se abrindo a uma corrente de vida divinal. A alma entra em comunicação com a graça e se eleva sobre seu ser e se percebe introduzida na mesma vida e ser de Deus. O estado da consciência torna-se, então, insusceptível de qualquer descrição verbal. Nesse particular, os mestres são unânimes. Por isso, Teresa D'Ávila e João da Cruz, assim descrevem a condição denominada união de amor, alcançada pela travessia da noite escura: momento em que o Eterno toca e reside na alma, mas de maneira tão obscura que a alma não encontra mais meios, nem comparações para traduzir a sublimidade e delicadeza do sentimento espiritual de que está cheia.

Trata-se de uma união de dois seres e de duas pessoas, união esta que não anula sua independência, mas, precisamente, a supõe e transforma. Essa comunicação e união, Stein irá descrever em seus mais diferentes graus, profundidade e desafios em A ciência da Cruz e irá produzir em sua leitura a certeza de que a existência não pode ser reduzida ao temporal, porque esta tem raízes na eternidade.

\section{CONSIDERAÇÕES FINAIS}

Há atualmente uma inquietação crescente, uma clara sensação de que algo falta ao humano. Um tempo onde verdades são relativizadas, o ser humano fragmentado e a fé lançada em um campo minado pela crítica pragmática secularizada. Para Stein, o humano alcança sua plenitude à medida que se cristifica e caminha rumo a uma união profunda com Deus. Toda essa problematização adquire mediante a revolução espiritual de Stein um novo ardor. Contudo, ela também adverte, "si non credideritis, non intelligetis" ${ }^{40}$. A vida guiada pelo conhecimento racional, por mais exímio que seja, estará sempre sujeita ao erro por consequência dos limites inerentes à natureza humana. Desse modo, há uma ressalva à fé, enquanto fator intelectual que envolve o ser humano como um todo, em seu natural caminho, mas que o conduz rumo ao sobrenatural, à profundidade mais íntima de seu existir em um encontro dinâmico da reciprocidade do amor que supera todas as coisas e eleva a alma para além daquilo que lhe é acessível naturalmente.

A incapacidade de compreender o estado das coisas pode ser superada ou sofrer cada vez mais o embotamento do sentido ao largo da vida em formação e em relação ao o mundo e a Deus. Entre verdades relativas e absolutas transita o ser dotado de potencialidades para discernir, encontrar e realizar a travessia rumo ao eterno. A realização da natureza do ser somente será possível quando forem desobstruídos os sentidos e o intelecto, numa jornada rumo à interioridade profunda que o eleva. Este é o espaço primordial onde o humano dá voz a seus íntimos desejos, discerne sobre eles, encontra a si mesmo e descobre Deus sempre presente e o orienta ao bem que se deve realizar.

A ciência da cruz que Stein escreve em poucos meses é uma jornada pessoal, um livro que revela uma teologia do abandono, uma mística que faz do humano um protagonista de Deus Redentor. Para tanto, há de se buscar, assim como o fez Stein, a verdade, o amor, e seu lugar no mundo. É preciso o exercício contínuo de desobstrução de tudo o que é possível interferir no caminho do ser que busca sentido, plenitude, eternidade.

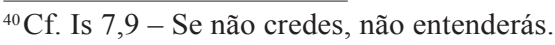




\section{REFERÊNCIAS}

BELLO, Angela Alles. Edith Stein: A Paixão pela Verdade. Curitiba: Juruá, 2014.

Teologia negativa, mística, hilética fenomenológica: a propósito de Edith Stein. Memorandum, v. 3, 2002, p. 98-111.

FERMÍN, Francisco Javier Sancho. Una espiritualidad para hoy según Edith Stein: 20 temas de estúdio e reflexión. Burgos: Monte Carmelo, 1998.

Líneas generales de la espiritualidad de Edith Stein. Centro Internacional (Ávila): Revista de Espirtualidad, 1999.

GARCIA, Jacinta; SCIADINI, Patrício. Edith Stein: Holocausto para seu povo. São Paulo: Edições Loyola, 1980.

JAMES, William. As variedades da experiencia religiosa. Um estudo sobre a natureza humana. São Paulo: Cultrix, 2017.

JOÃO PAULO II. Fides et Ratio. Carta Encíclica aos Bispos da Igreja sobre as relações entre fé e razão. São Paulo: Paulinas, 1998.

MIRIBEL DE, E. Edith Stein. Como ouro purificado pelo fogo. Aparecida, SP: Ed. Santuário, 2001.

NEMAZEE, R. "AVE CRUX, SPES ÚNICA": The theology of the cross in the life and Works of Edith Stein. Canadá: National Library of Canadá, 2000.

PARISE, Maria Cecília. As colorações da alma na análise da pessoa humana segundo Edith Stein. 2014. 233 f. Dissertação (Mestrado em Filosofia) - Universidade Federal de São Paulo, São Paulo, 2014.

PECORARO, Rossano. Cioran, a filosofia em chamas. Porto Alegre: EDIPUCRS, 2004.

PSEUDO-DIONISIO, Aeropagita. Teologia Mística. Medievalia 10. Textos e estudos. Gab. de filosofia medieval da Faculdade de Letras do Porto e da Faculdade de Teologia Católica do Porto, 1996.

RUS, Éric de. A visão educativa de Edith Stein. Aproximação a um gesto antropológico integral. Belo Horizonte: Ed. Artesã, 2015.

SAVIAN FILHO, Juvenal. Experiência mística e filosofia em Edith Stein. Kairós, Fortaleza, v. VIII, n. 2, jul./dez. 2011.

SBERGA, Adair Aparecida. A Formação da Pessoa em Edith Stein. São Paulo: Paulus, 2014.

SCIADINI, P. (Org.). Edith Stein, na força da cruz: seleção de textos de Waltraud. Vargem Grande Paulista: Cidade Nova, 2010.

STEIN, Edith. Obras completas: Escritos autobiográficos e cartas. Vol. I Madrid/Burgos: Vitoria Ediciones El Carmen/Editorial de Espiritualidad e Editorial Monte Carmelo, 2002.

Obras completas: Escritos filosóficos. Vol. II. Madrid/Burgos: Vitoria Ediciones El Carmen/ Editorial de Espiritualidad e Editorial Monte Carmelo, 2002.

. Obras completas: Escritos antropológicos y pedagógicos. Vol. IV. Madrid/Burgos: Vitoria Ediciones El Carmen/Editorial de Espiritualidad e Editorial Monte Carmelo, 2003.

. Obras completas: Escritos espirituales. Vol. V. Madrid/Burgos: Vitoria Ediciones El Carmen/ Editorial de Espiritualidad e Editorial Monte Carmelo, 2004.

Ser finito y ser eterno. Ensayo de una ascensión al sentido del ser. México: FSE, 1994. . Na força da cruz. São Paulo: Cidade Nova, 1984.

Recebido em: 29/05/2018

Aprovado em: 05/06/2018

Correspondência para:

Prof. Dr. Dom Leomar Brustolin

Escola de Humanidades

Pontifícia Universidade Católica do Rio Grande do Sul

Av. Ipiranga 6681 - Prédio 08, 4ㅇandar

90619-900 Porto Alegre, RS, Brasil 